Journal of
Nutrigenetics
and
Nutrigenomics
J Nutrigenet Nutrigenomics 2012;5:327-338

DOI: $10.1159 / 000345819$

Received: June 14, 2012

Accepted: November 6, 2012

Published online: January 16, 2013

\title{
Short-Term Folate Supplementation in Physiological Doses Has No Effect on ESR1 and MLH1 Methylation in Colonic Mucosa of Individuals with Adenoma
}

\author{
Reyad Al-Ghnaniem Abbadi ${ }^{a}$ Peter Emery ${ }^{a}$ Maria Pufulete ${ }^{a, b}$ \\ a Diabetes and Nutritional Sciences Division, King's College London, London, and \\ ${ }^{b}$ Clinical Trials and Evaluation Unit, School of Clinical Sciences, University of Bristol, \\ Bristol Royal Infirmary, Bristol, UK
}

\author{
Key Words \\ Folate $\cdot$ DNA methylation $\cdot$ ESR1 $\cdot \mathrm{MLH} 1 \cdot$ Adenoma $\cdot$ Colorectal cancer
}

\begin{abstract}
Background/Aims: Low folate intake may increase risk of colorectal cancer by altering genespecific methylation in the colon. We determined whether supplementation with physiological doses of folate could alter methylation in the oestrogen receptor 1 (ESR1) and mutL homolog 1 (MLH1) genes in colonic mucosa of subjects with colorectal adenoma. Methods: This was a randomised, double-blind, placebo-controlled trial. Subjects received either $400 \mu \mathrm{g} /$ day folic acid $(n=15)$ or placebo $(n=14)$ for 10 weeks. Blood and colonic tissue samples were collected at baseline and after intervention to determine biomarkers of folate and vitamin $B_{12}$ status, MTHFR C677T and MS A2756G genotypes, and ESR1 and MLH1 methylation. Results: Although serum and red cell folate increased ( $p<0.001$ vs. placebo) and plasma homocysteine decreased $(p=$ 0018 vs. placebo) in the folic acid group, there were no significant changes in ESR1 ( $p=0.649$ vs. placebo) or MLH1 ( $p=0.211$ vs. placebo) methylation. There was a significant effect of gender on ESR1 methylation ( $p=0.004)$ and significant gender and genotype (MTHFR C677T and MS A2756G) interactions ( $p=0.04$ and $p=0.014$, respectively) that were independent of treatment group allocation. Conclusions: Short-term folate supplementation in physiological doses decreases plasma homocysteine but has no effect on ESR1 and MLH1 methylation in colonic mucosa of individuals with adenoma. Further studies to investigate the interactions between gender, genotype and DNA methylation suggested in this study are warranted.
\end{abstract}

Copyright $\odot 2013$ S. Karger AG, Basel 


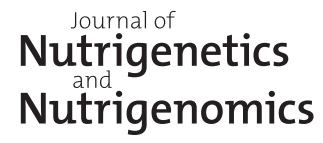

J Nutrigenet Nutrigenomics 2012;5:327-338

DOI: $10.1159 / 000345819$

Published online: January 16, 2013

(c) 2013 S. Karger AG, Basel

www.karger.com/jnn

Al-Ghnaniem Abbadi et al.: Short-Term Folate Supplementation in Physiological Doses Has No Effect on ESR1 and MLH1 Methylation in Colonic Mucosa of Individuals with Adenoma

\section{Introduction}

A low folate status may increase the risk of colorectal cancer [1] by altering normal patterns of DNA methylation [2]. Colorectal cancer is characterised by a genome-wide decrease in methylation (hypomethylation) [3] and an increase in methylation in CpG islands located in the promoter regions of tumour suppressor genes (hypermethylation) [4], which leads to transcriptional silencing [5-7]. Folate deficiency may precipitate these changes, since folate (as 5-methyltetrahydrofolate) is a methyl donor in the methylation cycle, which involves the remethylation of homocysteine to methionine and maintenance of biological methylation reactions. Common polymorphisms in genes involved in the methylation cycle [including methylenetetrahydrofolate reductase (MTHFR) and methionine synthase (MS)] are known to influence DNA methylation and risk of colorectal cancer [8].

Evidence suggests that folate plays a dual role in colorectal cancer, with suboptimal intakes increasing risk of neoplastic transformation in the normal colon, and high intakes promoting tumour growth in the context of established premalignant lesions [9]. The majority of folate chemopreventive trials have used individuals with colorectal adenoma (a premalignant lesion that is the precursor of cancer), but only after the adenoma/s had been removed. This would avoid the potential for folate to promote existing tumour growth, but possibly reduce the risk of new adenoma formation by preventing deleterious changes to DNA methylation.

Randomised controlled trials (RCTs) in subjects with adenoma suggest that pharmacological (1-10 mg/day) [10-12] and physiological (400 $\mu \mathrm{g} /$ day) [13] intakes of folic acid can increase genomic DNA methylation in colonic mucosa, although results have been inconsistent. There are two RCTs that have investigated the influence of pharmacological intakes of folic acid ( 1 and $5 \mathrm{mg} /$ day) on gene-specific methylation; one showed no effect after 3 years of supplementation [14], and the other suggested an increase in methylation in the folatesupplemented group at 6 months, although this was not significant [15]. However, these RCTs are not definitive; one coincided with the start of the folate fortification programme in the USA, which resulted in an increase in plasma folate and decrease in plasma homocysteine in the placebo group over time [14], while the other used a high dose of folic acid (5 mg/day), which does not reflect normal intake and, based on evidence from animal studies, may have unexpected effects. There have been no trials assessing the impact of a physiological dose of folate on gene-specific methylation. The aim of the present study was to determine whether supplementation with a physiological dose of folate ( $400 \mu \mathrm{g} /$ day) could alter methylation of CpG sites in the promoter regions of the oestrogen receptor 1 (ESR1) and mutL homolog 1 (MLH1) genes in normal-appearing mucosa of subjects with adenoma and adequate folate status. ESR1 mediates the biological function of the steroid hormone $17 \beta$-oestradiol, which is a critical regulator of growth, differentiation and function in a wide variety of tissues including colonic epithelium. MLH1 is a mismatch repair (MMR) gene that recognises and repairs errors that occur during DNA replication. These genes were chosen because they display increased methylation in colorectal tumours $[16,17]$ and normal-appearing colorectal mucosa of individuals with and without colorectal neoplasia $[16,18-20]$.

\section{Materials and Methods}

Thirty-one subjects with colorectal adenoma were consecutively recruited into a RCT designed to investigate the effect of folic acid supplementation ( $400 \mu \mathrm{g} /$ day for 10 weeks) on genome-wide methylation in normal-appearing colonic mucosa [13]. The sample size was calculated so as to detect a 1 SD change in genome-wide DNA methylation in colorectal mucosa with $80 \%$ power and an $\alpha$ error of 0.05 , which indicated 16 patients in each group. 


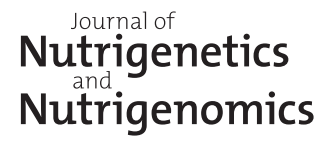

Jutrigenet Nutrigenomics 2012;5:327-338

DOI: $10.1159 / 000345819$

Published online: January 16,2013

(C) 2013 S. Karger AG, Base

www.karger.com/jnn

Al-Ghnaniem Abbadi et al.: Short-Term Folate Supplementation in Physiological Doses Has No Effect on ESR1 and MLH1 Methylation in Colonic Mucosa of Individuals with Adenoma

Subjects were recruited from a series of patients attending for clinically indicated colonoscopy at the Department of Colorectal Surgery, King's College Hospital, London, between August 2000 and March 2001. The only inclusion criterion was histologically confirmed colorectal adenoma at current colonoscopy. Exclusion criteria were current or previous diagnosis of colorectal cancer, a strong family history of colorectal cancer or adenomatous polyposis coli, inflammatory bowel disease, a current or past history of gluten-sensitive enteropathy, clinical and/or laboratory evidence of intestinal malabsorption, significant renal or liver disease, pregnancy, epilepsy, alcoholism, pernicious anaemia, serum vitamin $B_{12}$ levels $<180$ $\mathrm{ng} / \mathrm{l}$ and the use of anti-folate medication or dietary supplements containing folic acid and/or vitamin $\mathrm{B}_{12}$. We did not exclude subjects on the basis of use of folic acid fortified foods.

Patients had their weight and height recorded and provided information on smoking habits, current medication and supplement use and completed a specially designed food frequency questionnaire to assess dietary folate and alcohol intakes [21]. Patients were asked to bring in any medication and/or supplement containers to check that they were suitable for inclusion in the study. Patients were told about the potential benefits and risks of folic acid supplementation. Written informed consent was obtained from all patients according to the guidelines of the Research Ethics Committee at King's College Hospital NHS Trust and King's College London. Details of sample size calculation, randomisation, treatment allocation and trial flow diagram have been reported previously [13]. Briefly, patients were randomised to receive either $400 \mu \mathrm{g} / \mathrm{day}$ folic acid or an identical-looking placebo for 10 weeks. The randomization sequence was computer-generated in blocks of six and stratified by sex. All subjects, hospital and laboratory personnel involved in administering the interventions, collecting and analysis samples were blinded to intervention status. All results were analysed on an intention-to-treat basis.

\section{Blood and Tissue Sampling}

Fasting venous blood samples were obtained at baseline and after the intervention for determination of serum and red cell folate, plasma homocysteine and serum vitamin $B_{12}$ concentrations and MTHFR C677T and MS A2756G polymorphisms. Baseline rectal biopsies of normal-appearing mucosa for DNA extraction were obtained during the colonoscopy (baseline) and by rigid sigmoidoscopy after the treatment. On both occasions, mucosal biopsy specimens were removed from the rectum (about $12 \mathrm{~cm}$ from the anal verge) at least $5 \mathrm{~cm}$ from any lesion or mucosal abnormality and immediately snap frozen in liquid nitrogen. Blood samples were obtained on the day of colonoscopy prior to the procedure (baseline) and prior to rigid sigmoidoscopy (after intervention). Patients were asked to return their remaining supplement pills for counting to check compliance and were asked not to change their diet or lifestyle in any way during the study.

\section{Laboratory Methods}

Serum and red cell folate and vitamin $B_{12}$ were measured by competitive protein binding enzyme immunoassays on an Immuno 1 analyser (Bayer Diagnostics, Newbury, UK). Plasma homocysteine was measured using the Abbott IMx homocysteine assay (Abbott Laboratories, Abbott Park, Ill., USA). Coefficients of variation for these assays ranged from 4.6 to $6.7 \%$. Global DNA methylation was determined by the in vitro methyl acceptance method using $\left[{ }^{3} \mathrm{H}\right.$-methyl] $S$-adenosylmethionine as a methyl donor in the presence of the Sss I prokaryotic methylase enzyme [22].

MTHFR C677T and MS A2756G genotypes were determined by PCR amplification of genomic DNA extracted from leucocytes using appropriate forward and reverse primers [23] and restriction enzyme digestion.

DNA extracted from colonic tissue samples (using Puregene DNA isolation kits, Gentra Systems, Inc., Minneapolis, Minn., USA) and stored at $-70^{\circ} \mathrm{C}$ was used for the determination of ESR 1 and MLH1 promoter methylation. DNA size ( $>20 \mathrm{~kb}$ in all samples), concentration and purity (determined using the NanoDrop ${ }^{\circledR}$ ND-1000 UV spectrophotometer) were established in all samples. Bisulfite modification of DNA (500 ng per sample) was carried out using the EZ DNA Methylation-Gold Kit ${ }^{\mathrm{TM}}$ (Zymo Research, Irvine, Calif., USA) according to the manufacturer's protocol. This converts unmethylated cytosines, by a process of deamination, to uracil leaving the methylated cytosines unchanged. The converted DNA was eluted in $10 \mu \mathrm{l}$ of $1 \times \mathrm{TE}$ buffer and stored at $-20^{\circ} \mathrm{C}$ until use. Normal human blood donor DNA was used as a negative control and also methylated in vitro using SssI (CpG) methylase (New England Biolabs, Ipswich, Mass., USA) for use as a positive control.

Methylation of 7 and 13 CpG sites in ESR1 and MLH1, respectively, was determined by pyrosequencing. In ESR1, the CpG sites chosen were on the coding sequence on exon 1 positions 189, 192, 194, 198, 


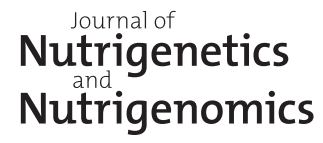

J Nutrigenet Nutrigenomics 2012;5:327-338

DOI: $10.1159 / 000345819$

Published online: January 16, 2013

(c) 2013 S. Karger AG, Basel

www.karger.com/jnn

201, 207 and 209. This included a Not1 recognition site, which has been shown to display age-related methylation in individuals without colorectal neoplasia [16]. For MLH1, thirteen CpG sites 700 bp upstream of the promoter (located at bases $-694,-688,-674,-672,-670,-624,-616,-609,-606,-604,-600,-598$ and -588) were chosen for the assay design. CpG sites in this area were chosen because methylation in this region has been demonstrated in normal mucosa from subjects with colorectal cancer [20,24] and has been associated with age in some studies $[19,20]$. The methods have been described in detail previously [18]. Briefly, forward and reverse (biotinylated) PCR primers (ESR1: GAGGTGTATTTGGATAGTAGTAAGTT; CTATTAAATAAAAAAAAACCCCCCAA; MLH1: AGTTTTTTTTTTAGGAGTGAAGG; ATAAAACCCTATACCTAATCTATC), designed using the PSQ Assay Design Software (formerly Biotage $\mathrm{AB}$, now Qiagen, UK), were used to amplify the bisulfite-modified DNA. The PCR mix (50 $\mu$ l volume) included: $50 \mathrm{ng}$ bisulfite-converted DNA; $10 \mathrm{pM}$ of forward and reverse primer; $10 \times$ PCR buffer (containing $1.5 \mathrm{mM} \mathrm{MgCl}_{2}$ ); $1.5 \mathrm{mM}$ additional $\mathrm{MgCl}_{2}, 200 \mu \mathrm{M}$ of each dNTP, $1.25 \mathrm{U}$ HotStarTaq DNA polymerase (Qiagen, UK) and nuclease free water to make up to final volume. Cycling conditions were: $95^{\circ} \mathrm{C}$ for 15 min; 45 cycles of $\left(95^{\circ} \mathrm{C} 20 \mathrm{~s} ; 54^{\circ} \mathrm{C} 20 \mathrm{~s} ; 72^{\circ} \mathrm{C} 20 \mathrm{~s}\right) ; 72^{\circ} \mathrm{C} 5 \mathrm{~min} ; 4^{\circ} \mathrm{C}$ hold. Pyrosequencing was carried out using the PSQ ${ }^{\mathrm{TM}} \mathrm{HS} 96$ system (formerly Biotage AB, now Qiagen, UK). Sample preparation was carried out using the PyroMark Vacuum Prep Workstation: $10 \mu$ PCR product (biotinylated strand only) was immobilised to $2 \mu \mathrm{l}$ Streptavidin Sepharose ${ }^{\circledR}$ HP beads (GE Healthcare, formerly Amersham Biosciences) and released onto a PSQ HS 96 plate containing 10 pM sequencing primer (ESR1: GAGGGGTGTTTAGAGTTTA; MLH1: GTAGTATTGTGTTTAGTTT and AGGTTAGGGTAAGTGTTTTGA) and annealed for $2 \mathrm{~min}$ at $80^{\circ} \mathrm{C}$. Sequencing was carried out on the PSQ ${ }^{\mathrm{TM}} \mathrm{HS} 96$ system according to standard procedures. Within-run and between-run coefficients of variation for both assays were 1.6 and $5 \%$, respectively.

\section{Statistical Analysis}

Data were analysed using the Statistical Package for Social Sciences (SPSS, version 13.0). An average methylation value (arithmetic mean) across all CpG sites (7 for ESR1 and 13 for MLH1) was calculated for each gene. $\chi^{2}$ test or Fisher's exact test was used as appropriate to compare categorical variables at baseline (gender, smoking, alcohol intake and genotypes). Differences in continuous variables at baseline were compared using independent sample t tests (serum and red cell folate, serum vitamin $\mathrm{B}_{12}$, plasma homocysteine, genomic DNA methylation and ESR1 methylation) or Mann Whitney U tests where data were not normally distributed (body mass index, MLH1 methylation). Paired sample t tests were used to compare values between baseline and after intervention in the folic acid and placebo groups.

In order to assess changes between the two time points in biomarkers of folate status (serum and red cell folate, plasma homocysteine and genomic DNA methylation), baseline values were subtracted from post-intervention values for each subject. The mean differences for each variable were compared using independent samples $t$ tests (difference in red cell folate) or Mann Whitney U test for variables that were not normally distributed (differences in serum folate and plasma homocysteine).

Analysis of covariance (ANCOVA) was carried out to assess the effect of folate supplementation compared with placebo on ESR1 methylation in normal-appearing colorectal mucosa, with the baseline methylation used as a covariate in addition to age, gender, body mass index, smoking, alcohol and folate intake and genotypes (MTHFR C677T and MS A2756G). Factors used to describe the subjects' characteristics and their significant interactions were used to construct the statistical model. Subjects who were heterozygous (CT) or mutant (TT) for the MTHFR C677T mutation were combined into a single group to lessen the skewing effect produced by small numbers. The Kruskal-Wallis test was used to compare the change in MLH1 methylation after the intervention in the folic acid group compared with placebo as this variable was not normally distributed.

\section{Results}

Subject characteristics are shown in table 1. Data were analysed for 29 subjects (14 in the placebo group, 15 in the folic acid group) because there were no DNA samples available for 2 subjects from the placebo group. Patients in the placebo group were more likely to be smokers $(p=0.014)$, but there were no differences in age, body mass index, folate intakes or the 
Table 1. Subjects' characteristics in the placebo and folic acid groups

\begin{tabular}{lccl}
\hline & Placebo $(\mathrm{n}=14)$ & Folic acid $(\mathrm{n}=15)$ & p value \\
\hline Male gender & $11(79)$ & $10(67)$ & 0.682 \\
Age, years & $63.2(57.8-68.7)$ & $63.9(57.3-70.5)$ & 0.859 \\
Body mass index & $24.4(19.8-29.5)$ & $25.3(19.8-49.4)$ & 0.331 \\
Folate intake, $\mu$ g/day & $370(277-463)$ & $341(276-406)$ & 0.585 \\
Serum vitamin B $_{12}$ pmol/l & $354(255-452)$ & $329(244-436)$ & 0.834 \\
Alcohol intake & & & \\
$\quad$ Lower third $(<2$ g/day) & $2(14)$ & $7(47)$ & 0.114 \\
$\quad$ Middle third $(2-37$ g/day) & $5(36)$ & $5(33)$ & \\
$\quad$ Upper third (>37 g/day) & $7(50)$ & $3(20)$ & 0.014 \\
Current smoker & $7(50)$ & $1(7)$ & 0.552 \\
MTHFR C677T genotype & & $10(67)$ & \\
$\quad$ CC & $8(57)$ & $5(33)$ & \\
CT & $5(36)$ & 0 & 0.272 \\
TT & $1(7)$ & $10(67)$ & \\
MS A275G genotype & $6(43)$ & $5(33)$ & \\
AA & $8(57)$ & 0 & \\
AG & 0 & & \\
GG & &
\end{tabular}

Values are mean $(95 \% \mathrm{CI})$ for age, folate intake and serum vitamin $\mathrm{B}_{12}$, median (range) for body mass index, and number (\%) for gender, alcohol intake, smoking and genotype.

distribution of gender and genetic polymorphisms in enzymes involved in the methylation cycle.

There were no significant differences in biomarkers of folate status, serum vitamin $B_{12}$ or genomic DNA methylation between the two groups at baseline (table 2). In the folic acid group, the increase in serum and red cell folate ( $<<0.001$ vs. placebo) and the decrease in plasma homocysteine ( $\mathrm{p}=0018 \mathrm{vs}$. placebo) were significantly greater than the corresponding changes in the placebo group.

The percentage methylation by $\mathrm{CpG}$ site and the average percentage methylation for all sites for ESR1 in normal-appearing colorectal mucosa at baseline and after intervention in the placebo and folic acid groups are shown in table 3 . There were no significant differences in the average methylation between the two groups at baseline $(\mathrm{p}>0.05)$ or between baseline and after intervention in the folic acid and placebo groups ( $\mathrm{p}>0.05)$, although there was a trend for increased methylation in all CpG sites in the folic acid group (fig. 1).

ANCOVA was carried out to assess the effect of folate supplementation compared with placebo on ESR1 methylation in normal-appearing colorectal mucosa. Covariates used in the model were baseline ESR1 methylation, age, gender, body mass index, smoking, alcohol and folate intake and genotypes. The adjusted means for factors found to be significant in the model are shown in table 4 . There was no effect of folate supplementation on average ESR1 methylation after intervention $(\mathrm{p}=0.649)$. There was a significant effect of gender, with average ESR1 methylation in women showing a significant increase after intervention compared with males regardless of the treatment group to which they were allocated $(p=0.004)$. There were also significant interactions between gender and MTHFR C677T and MS A2756G genotypes. Women with the MTHFR C677T CT or TT genotype had increased ER methylation compared with wild-type women $(\mathrm{p}=0.04)$, whereas there was no difference between genotypes among the men. Conversely, women with the MS A2756G AA genotype had in- 
Table 2. Biomarkers of folate status in the placebo and folic acid groups

\begin{tabular}{|c|c|c|c|}
\hline & Placebo $(\mathrm{n}=14)$ & Folic acid $(\mathrm{n}=15)$ & $\mathrm{p}$ value \\
\hline \multicolumn{4}{|l|}{ Baseline values } \\
\hline Serum folate, $\mathrm{nmol} / \mathrm{l}$ & $18.6(14.0$ to 23.3$)$ & $17.2(12.7$ to 21.5$)$ & 0.609 \\
\hline Red cell folate, $\mathrm{nmol} / \mathrm{l}$ & $709(557$ to 861$)$ & $634(489$ to 780$)$ & 0.454 \\
\hline Plasma total homocysteine, $\mu \mathrm{mol} / \mathrm{l}$ & $11.1(9.0$ to 13.2$)$ & $14.2(10.2$ to 18.3$)(\mathrm{n}=14)$ & 0.168 \\
\hline Genomic DNA methylation, $\mathrm{Bq} / \mu \mathrm{g}$ DNA & 474 (394 to 555$)$ & $574(480$ to 669$)$ & 0.097 \\
\hline \multicolumn{4}{|l|}{ Changes after intervention } \\
\hline Serum folate, $\mathrm{nmol} / \mathrm{l}^{1}$ & $-0.5(-14.0$ to 2.9$)$ & $14.3(-5.4$ to 26.7$)(\mathrm{n}=14)$ & $<0.001$ \\
\hline Red cell folate, $\mathrm{nmol} / \mathrm{l}$ & $-18(-122$ to 86$)$ & $369(195$ to 546$)$ & 0.001 \\
\hline Plasma total homocysteine, $\mu \mathrm{mol} / \mathrm{l}^{1}$ & $0.2(-2.7$ to 4.0$)$ & $-1.2(-26.9$ to 2.5$)$ & 0.018 \\
\hline Genomic DNA methylation, $\mathrm{Bq} / \mu \mathrm{g}$ DNA & $-52(-108$ to 3$)$ & $-117(-215$ to -19$)$ & 0.236 \\
\hline
\end{tabular}

Values are mean $(95 \% \mathrm{CI})$ unless otherwise stated. ${ }^{1}$ Median (range).

Table 3. ESR1 and MLH1 methylation (\%) by CpG site in the placebo and folic acid groups at baseline and after intervention

\begin{tabular}{|c|c|c|c|c|}
\hline \multirow[t]{2}{*}{ Site } & \multicolumn{2}{|l|}{ Baseline } & \multicolumn{2}{|l|}{ After intervention } \\
\hline & placebo $(\mathrm{n}=14)$ & folic acid $(n=15)$ & placebo $(\mathrm{n}=14)$ & folic acid $(n=15)$ \\
\hline \multicolumn{5}{|l|}{ ESR1 } \\
\hline 1 & $13.3(9.4-17.2)$ & $12.7(10.8-14.5)$ & $13.0(9.8-16.2)$ & $14.3(10.9-17.7)$ \\
\hline 2 & $13.7(10.1-17.3)$ & $13.5(11.7-15.2)$ & $12.5(9.5-15.4)$ & $14.0(10.9-17.1)$ \\
\hline 3 & $10.6(7.4-13.9)$ & $10.4(8.9-11.9)$ & $9.9(7.2-12.6)$ & $11.1(8.2-14.0)$ \\
\hline 4 & $15.2(11.0-19.4)$ & $15.0(13.0-16.9)$ & $14.5(11.4-17.6)$ & $16.6(13.4-19.9)$ \\
\hline 5 & $15.8(11.6-20.0)$ & $15.5(13.7-17.4)$ & $15.1(11.8-18.4)$ & $16.5(12.8-20.2)$ \\
\hline 6 & $15.8(11.8-19.8)$ & $16.1(14.2-18.0)$ & $15.3(11.9-18.7)$ & $16.8(13.2-20.3)$ \\
\hline 7 & $10.5(7.5-13.5)$ & $10.2(9.0-11.5)$ & $10.3(7.7-13.0)$ & $11.2(8.5-13.9)$ \\
\hline Average methylation & $13.6(9.9-17.3)$ & $13.3(11.6-15.0)$ & $12.9(9.9-16.0)$ & $14.3(11.1-17.6)$ \\
\hline \multicolumn{5}{|l|}{ MLH1 } \\
\hline 1 & $1.2(0.0-2.3)$ & $1.2(0.9-2.7)$ & $1.0(0.0-1.6)$ & $1.0(0.0-1.3)$ \\
\hline 2 & $2.0(1.5-3.5)$ & $2.1(1.6-3.5)$ & $1.5(1.2-2.8)$ & $1.5(1.1-2.0)$ \\
\hline 3 & $1.0(0.0-2.0)$ & $1.0(0.0-2.0)$ & $0.9(0.0-1.0)$ & $0.8(0.0-1.0)$ \\
\hline 4 & $1.9(1.5-2.8)$ & $1.8(1.3-3.2)$ & $1.5(1.2-2.4)$ & $1.4(1.2-1.7)$ \\
\hline 5 & $1.3(0.0-3.0)$ & $1.6(1.0-3.0)$ & $1.1(0.0-1.8)$ & $1.0(0.0-1.2)$ \\
\hline 6 & $2.3(1.4-4.5)$ & $2.4(2.0-4.6)$ & $2.0(2.0-3.0)$ & $1.9(2.0-3.0)$ \\
\hline 7 & $1.3(0.0-3.0)$ & $1.3(1.0-3.0)$ & $1.1(0.9-2.0)$ & $1.1(0.8-1.4)$ \\
\hline 8 & $3.1(1.6-5.2)$ & $3.1(2.2-5.3)$ & $2.2(1.9-3.4)$ & $2.2(1.5-2.6)$ \\
\hline 9 & $1.4(0.0-3.0)$ & $1.6(0.0-3.0)$ & $1.2(0.0-2.1)$ & $1.1(0.0-1.6)$ \\
\hline 10 & $2.8(2.0-5.0)$ & $3.0(2.0-5.0)$ & $2.3(1.7-3.3)$ & $1.9(1.7-3.0)$ \\
\hline 11 & $3.1(2.0-8.0)$ & $3.6(3.0-6.0)$ & $2.9(2.2-4.6)$ & $2.8(2.2-4.0)$ \\
\hline 12 & $2.1(2.0-6.0)$ & $2.8(2.0-5.0)$ & $1.7(1.2-3.2)$ & $1.7(1.0-2.0)$ \\
\hline 13 & $2.3(2.0-5.0)$ & $2.5(2.0-4.0)$ & $1.9(1.1-3.3)$ & $1.8(1.3-2.0)$ \\
\hline Average methylation & $2.0(1.4-4.1)$ & $2.0(1.6-3.8)$ & $1.6(1.3-2.7)$ & $1.5(1.2-1.8)$ \\
\hline
\end{tabular}

For ESR1, values are mean (95\% CI). For MLH1, values are median (range). 


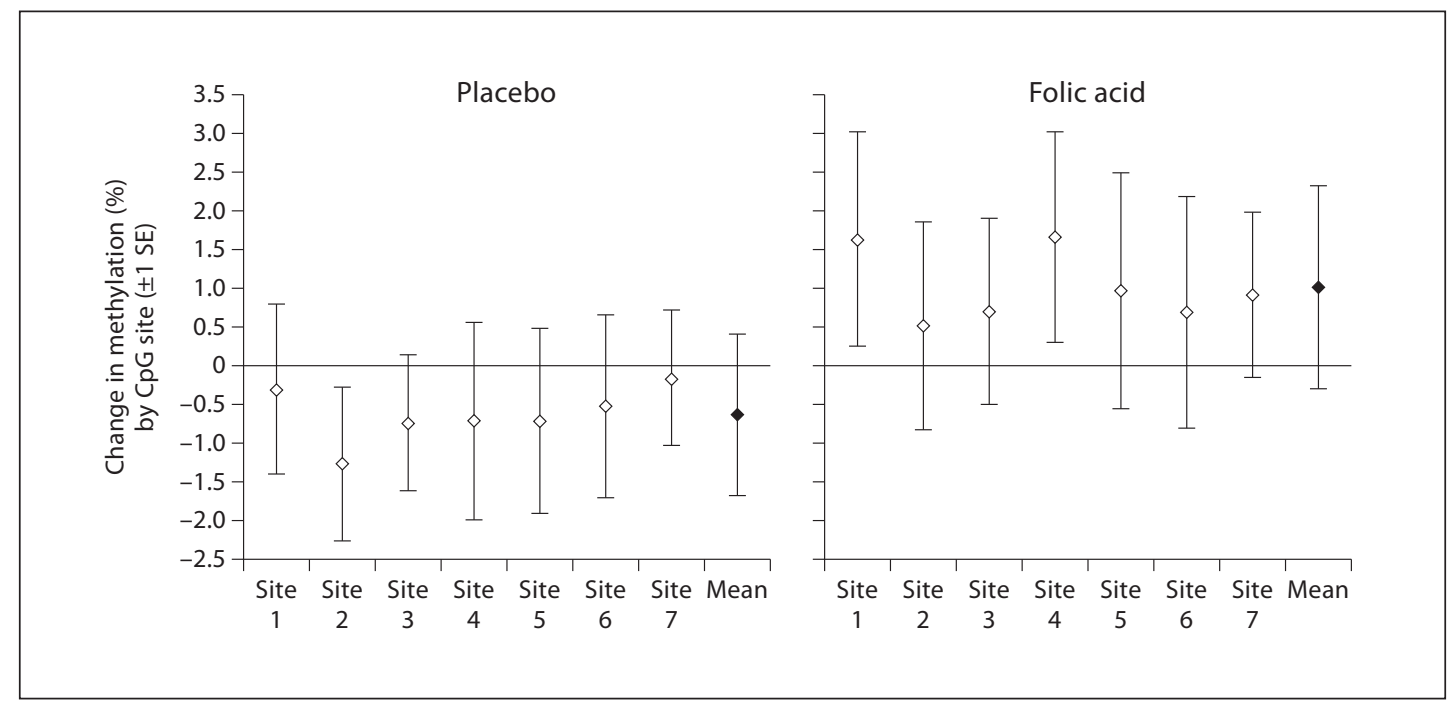

Fig. 1. Mean change in ESR1 methylation between the two time points (baseline and after intervention) in the placebo and folic acid groups.

Table 4. Adjusted means for factors in ANCOVA model ${ }^{1}$

\begin{tabular}{ll}
\hline Factor & Mean $(95 \% \mathrm{CI})$ \\
\hline Intervention status & \\
$\quad$ Placebo & $15.2(13.0-17.5)$ \\
$\quad$ Folic acid & $14.6(12.6-16.6)$ \\
Gender & $12.4(10.7-14.0)$ \\
$\quad$ Male & $17.5(14.8-20.2)$ \\
Female & \\
Gender $\times$ MTHFR C677T & $13.3(11.3-15.3)$ \\
$\quad$ Male & $11.4(8.6-14.2)$ \\
$\quad$ CC & \\
CT or TT & $14.9(10.9-19.0)$ \\
Female & $20.0(16.4-23.6)$ \\
$\quad$ CC & \\
CT or TT & $11.9(9.9-14.0)$ \\
Gender $\times$ MS A2756G & $12.8(10.2-15.3)$ \\
Male & $21.1(16.7-25.6)$ \\
AA & $13.8(10.6-17.0)$ \\
AG or GG &
\end{tabular}

${ }^{1}$ ANCOVA was used to test the effect of folate supplementation on ESR1 methylation in colonic mucosa after intervention. Baseline ESR1 methylation was used as a covariate in addition to age, gender, body mass index, smoking, alcohol and folate intake and genotypes. Only gender $(\mathrm{p}=0.004)$ and gender-genotype interaction ( $\mathrm{p}=0.04$ for MTHFR C677T and $\mathrm{p}=0.014$ for MS A2756G) were found to be significantly associated with ESR1 methylation in colonic mucosa after intervention (adjusted means shown in the table), independent of treatment group allocation. Covariates appearing in the model are evaluated at the following values: baseline average methylation $=13.5$. 
creased methylation compared with those carrying the AG or GG genotype ( $p=0.014$ ), while again there was no difference between genotypes among men. These changes were independent of treatment group allocation. The model was then run for the different CpG sites investigated. There was general agreement with the previous model except that the $\mathrm{p}$ value for the gender and MTHFR C677T interaction was only significant $(\mathrm{p}<0.05)$ at sites 2,3 and 7.

The percentage methylation by $\mathrm{CpG}$ site and the average percentage methylation for all sites for MLH1 in normal-appearing colorectal mucosa at baseline and after intervention in the folic acid and placebo groups are shown in table 3. There were no significant differences in the average MLH1 methylation between the two groups at baseline or between baseline and after intervention in the folic acid and placebo groups $(\mathrm{p}<0.05)$. The change in the folic acid group was not significant when compared with the placebo group $(\mathrm{p}=0.211)$. The level of methylation in MLH1 was $<5 \%$ at most sites both at baseline and after treatment (table 3); therefore, meaningful interpretation of any statistical models was not possible.

\section{Discussion}

The aim of the present study was to determine whether a physiological dose of folate could alter gene-specific methylation in normal-appearing colonic mucosa of subjects with adenoma who had adequate folate and vitamin $\mathrm{B}_{12}$ status at baseline. Folic acid supplementation had no effect on ESR1 and MLH1 methylation, either across individual CpG sites or the average methylation across all sites, despite significant increases in serum and red cell folate (by 83 and 58\%, respectively) and a significant decrease in plasma homocysteine (by $8 \%$ ) in the folate-supplemented group, with no corresponding changes in the placebo group. However, we did observe an apparent increase in methylation across all CpG sites in the ESR1 in the folic acid group after intervention (fig. 1), which disappeared after adjustment for various factors.

Although there have been two larger RCTs that have investigated the influence of increasing folate status on gene-specific methylation in individuals with adenoma [14, 15], they do not provide definitive conclusions. In the RCT testing the efficacy of aspirin, folic acid, or both, in the prevention of colorectal adenomas, a sub-group of 388 participants had methylation of ESR1 and secreted frizzled related protein-1 (SFRP1) genes determined in normalappearing colorectal mucosa [14]. There was no effect of folic acid supplementation ( $1 \mathrm{mg} /$ day) on methylation in either gene after 3 years of supplementation $(\mathrm{p}=0.35)$ [14]. However, recruitment in this study coincided with the start of the mandatory folate fortification of the food supply in the USA, which increased plasma homocysteine and decreased plasma folate in the placebo group over time and is likely to have influenced the results. Also, the subjects in this study differed in several respects from subjects in our study: they were younger (57 vs. 63 years) and had higher folate status at baseline, with higher plasma folate ( $24 \mathrm{vs} .18$ $\mathrm{nmol} / \mathrm{l})$ and lower plasma homocysteine ( $9.8 \mathrm{vs.} 12.7 \mathrm{nmol} / \mathrm{l})$. It is reasonable to assume that any effects of folate supplementation on DNA methylation are more likely to be observed in individuals with lower folate status. Also, in a study with a long intervention period and no interim time points, it is difficult to separate the effects of folic acid from other potential environmental modifiers of DNA methylation; a previous RCT in subjects with adenoma showed that folic acid supplementation influenced genomic DNA methylation at 6 months but not 1 year [12].

In the RCT by van den Donk et al. [15], $5 \mathrm{mg} /$ day folic acid administered for 6 months in 86 patients with previously resected adenoma resulted in an increased likelihood of higher promoter methylation in six tumour suppressor (APC, p14, p16, RASSF1A, MGMT and MLH1) genes, which tended to occur more often in the intervention group than in the pla- 
cebo group but was not significant $(\mathrm{OR}=1.67, \mathrm{p}=0.08)$. However, the high dose of folic acid used in this study prevents generalizability of the results to lower doses. Results from animal studies suggest that although folate supplementation is protective when administered at lower doses, it enhances the development of neoplasms at very high doses $[25,26]$. High doses of folate have been shown to adversely affect DNA methylation; Belshaw et al. [27] showed that mice fed a diet containing $8 \mathrm{mg} / \mathrm{kg}$ folic acid for 6 months had significantly increased ESR1 promoter methylation compared with mice fed no folic acid $(\mathrm{p}<0.01)$. In another animal study, a high intake of methyl group donors including folate has been shown to cause transcriptional silencing via increased methylation [28].

There have been no RCTs that have investigated the effect of folate supplementation on both genomic and gene-specific methylation in humans. Although our study is small and the effects are not significant, there is the suggestion that folate supplementation may increase both genomic and gene-specific DNA methylation. At first glance, this is counterintuitive, since genomic hypomethylation and gene-specific hypermethylation co-exist in tumours and have also been observed in normal mucosa from individuals with colorectal polyps [18, 29], and folate might be expected to benefit both processes. However, the two phenomena are not related in colorectal cancer and appear to contribute independently to neoplasia [30-32]. It is not known whether and how genomic hypomethylation and gene-specific hypermethylation are linked and which occurs first in the development of neoplasia. However, given the highly complex relationship between folate exposure and DNA methylation, further human studies investigating the two phenomena simultaneously are warranted.

It is unclear whether minor alterations in DNA methylation influence risk of neoplastic transformation. It has been argued that methylation levels such as those observed in the present study for the ESR1 gene (about 13\%) are biologically insignificant because they are too low to have any measurable effects on gene expression [33]. However, it has been shown that methylation in the ESR1 promoter occurs in an allele-specific manner in colonic cells; that is, the promoter regions of genes in some individual cells become fully methylated among many other cells which remain unmethylated [27]. Because methylation in a quantitative assay such as pyrosequencing represents an average across a population of cells, a $13 \%$ level may represent a small population of cells with fully methylated alleles in a largely unmethylated field. Thus, small changes in methylation may represent an increase in the number of cells with methylated alleles, which may increase the risk of neoplasia in these cells by silencing relevant tumour suppressor genes. For example, it has been shown that in the normal mucosa of individuals with colorectal cancer there are small foci of colonic epithelial cells among a largely 'healthy' cell population that have hypermethylation in the MLH1 promoter and lack MLH1 RNA and protein expression [34]. It is possible that increased folate intake in such individuals will promote the growth of a population of cells with methylation abnormalities, although the evidence for this is lacking.

In our study, we found that changes in ESR1 methylation from baseline were associated with female gender independent of intervention status, with women showing significantly increased ESR1 methylation after intervention regardless of treatment allocation. The reason for this is unclear and may be related to changes in lifestyle or dietary factors during the intervention, although we did not assess these, since our food frequency questionnaire was only administered at baseline and was not designed to assess nutrients other than folate. Other dietary factors, such as methionine, vitamin $\mathrm{B}_{2}$ and vitamin $\mathrm{B}_{6}$, are also involved in the folate-mediated one-carbon metabolism, and therefore have the potential to modulate DNA methylation. However, it is difficult to draw conclusions from our study because the sample size was relatively small. Some studies report no association between gene-specific methylation in colorectal mucosa and gender $[14,35]$. Other studies have noted associations with gender, although results are contradictory, with some suggesting higher methylation 


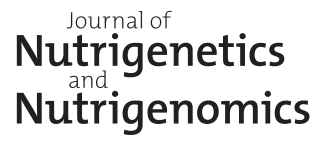

J Nutrigenet Nutrigenomics 2012;5:327-338

\begin{tabular}{l|l} 
DOI: $10.1159 / 000345819$ & (c) 2013 S. Karger AG, Basel
\end{tabular}

Published online: January 16, 2013

www.karger.com/jnn

Al-Ghnaniem Abbadi et al.: Short-Term Folate Supplementation in Physiological Doses Has No Effect on ESR1 and MLH1 Methylation in Colonic Mucosa of Individuals with Adenoma

levels in men [36] or women [19]. However, there is some evidence that aspects of the diet have gender-specific effects on gene-specific methylation and mutations in tumours of subjects of colorectal cancer [37], so our finding does warrant further investigation.

Interestingly, we also found significant interactions between ESR1 methylation, gender and genotype. For MTHFR C677T genotype, women carrying one or two variant alleles (CT or TT) showed increased ESR1 methylation after intervention compared with CC women or all men. The opposite effect was observed for the MS A2756G genotype; women with the wild-type allele (AA) had significantly higher ESR1 methylation after intervention than AG or GG women or all men. It is difficult to draw clear conclusions from the present study because of the small sample size and the fact that the study was not designed to test such interactions, although such interactions do not seem implausible. Several studies have shown interactions between genetic variants in folate-metabolizing enzymes, gender and gene-specific methylation $[38,39]$.

In summary, the present study did not show statistically significant changes in ESR1 and MLH1 methylation following short-term supplementation with a physiological dose of folic acid in individuals with colorectal adenoma. As methylation levels in MLH1 were $<5 \%$ both before and after the intervention, it was not possible to interpret the data with confidence as this level of methylation was less than the between-run coefficient of variation for the pyrosequencing assay (5\%). The main limitation of this study is the small sample size and number of genes studied. Larger, well-designed studies are needed to determine the role of dietary folate intake and how it interacts with common polymorphisms in folate-metabolising enzymes to determine gene-specific DNA methylation.

\section{Funding}

This study was institutionally funded.

\section{Disclosure Statement}

There are no potential conflicts of interest.

\section{References}

1 Kennedy DA, Stern SJ, Moretti M, Matok I, Sarkar M, Nickel C, Koren G: Folate intake and the risk of colorectal cancer: a systematic review and meta-analysis. Cancer Epidemiol 2011;35:2-10.

$\longrightarrow 2$ Mason JB, Choi SW: The mechanisms by which folate depletion enhances colorectal carcinogenesis: a unified scheme. Nestle Nutr Workshop Ser Clin Perform Programme 2000;4:87-99; discussion 99-101.

-3 Goelz SE, Vogelstein B, Hamilton SR, Feinberg AP: Hypomethylation of DNA from benign and malignant human colon neoplasms. Science 1985;228:187-190.

4 Baylin SB, Herman JG, Graff JR, Vertino PM, Issa JP: Alterations in DNA methylation: a fundamental aspect of neoplasia. Adv Cancer Res 1998;72:141-196.

5 Esteller M, Corn PG, Urena JM, Gabrielson E, Baylin SB, Herman JG: Inactivation of glutathione S-transferase P1 gene by promoter hypermethylation in human neoplasia. Cancer Res 1998;58:4515-4518.

-6 Herman JG, Umar A, Polyak K, Graff JR, Ahuja N, Issa JP, Markowitz S, Willson JK, Hamilton SR, Kinzler KW, Kane MF, Kolodner RD, Vogelstein B, Kunkel TA, Baylin SB: Incidence and functional consequences of hMLH1 promoter hypermethylation in colorectal carcinoma. Proc Natl Acad Sci USA 1998;95:6870-6875.

7 Myohanen SK, Baylin SB, Herman JG: Hypermethylation can selectively silence individual p16ink4A alleles in neoplasia. Cancer Res 1998;58:591-593.

8 Coppede F: Epigenetic biomarkers of colorectal cancer: focus on DNA methylation. Cancer Lett 2011, E-pub ahead of print.

9 Ulrich CM: Folate and cancer prevention: a closer look at a complex picture. Am J Clin Nutr 2007;86:271-273. 


\section{Nutrigenetics Nutrigenomics}

\begin{tabular}{l|l|}
\hline J Nutrigenet Nutrigenomics 2012;5:327-338 \\
\hline DOI: 10.1159/000345819 & $\begin{array}{l}\text { @ } 2013 \text { S. Karger AG, Basel } \\
\text { www.karger.com/jnn }\end{array}$ \\
\hline Published online: January 16, 2013 &
\end{tabular}

Al-Ghnaniem Abbadi et al.: Short-Term Folate Supplementation in Physiological Doses Has No Effect on ESR1 and MLH1 Methylation in Colonic Mucosa of Individuals with Adenoma

10 Cravo M, Fidalgo P, Pereira AD, Gouveia-Oliveira A, Chaves P, Selhub J, Mason JB, Mira FC, Leitao CN: DNA methylation as an intermediate biomarker in colorectal cancer: modulation by folic acid supplementation. Eur J Cancer Prev 1994;3:473-479.

11 Cravo ML, Pinto AG, Chaves P, Cruz JA, Lage P, Nobre Leitao C, Costa Mira F: Effect of folate supplementation on DNA methylation of rectal mucosa in patients with colonic adenomas: correlation with nutrient intake. Clin Nutr 1998;17:45-49.

12 Kim YI, Baik HW, Fawaz K, Knox T, Lee YM, Norton R, Libby E, Mason JB: Effects of folate supplementation on two provisional molecular markers of colon cancer: a prospective, randomized trial. Am J Gastroenterol 2001;96:184-195.

13 Pufulete M, Al-Ghnaniem R, Khushal A, Appleby P, Harris N, Gout S, Emery PW, Sanders TA: Effect of folic acid supplementation on genomic DNA methylation in patients with colorectal adenoma. Gut 2005;54:648-653.

14 Wallace K, Grau MV, Levine AJ, Shen L, Hamdan R, Chen X, Gui J, Haile RW, Barry EL, Ahnen D, McKeown-Eyssen G, Baron JA, Issa JP: Association between folate levels and CpG island hypermethylation in normal colorectal mucosa. Cancer Prev Res (Phila) 2010;3:1552-1564.

15 van den Donk M, Pellis L, Crott JW, van Engeland M, Friederich P, Nagengast FM, van Bergeijk JD, de Boer SY, Mason JB, Kok FJ, Keijer J, Kampman E: Folic acid and vitamin B-12 supplementation does not favorably influence uracil incorporation and promoter methylation in rectal mucosa DNA of subjects with previous colorectal adenomas. J Nutr 2007;137:2114-2120.

-16 Issa JP, Ottaviano YL, Celano P, Hamilton SR, Davidson NE, Baylin SB: Methylation of the oestrogen receptor CpG island links ageing and neoplasia in human colon. Nat Genet 1994;7:536-540.

17 Toyota M, Ahuja N, Ohe-Toyota M, Herman JG, Baylin SB, Issa JP: CpG island methylator phenotype in colorectal cancer. Proc Natl Acad Sci USA 1999;96:8681-8686.

18 Al-Ghnaniem R, Peters J, Foresti R, Heaton N, Pufulete M: Methylation of estrogen receptor alpha and mutL homolog 1 in normal colonic mucosa: association with folate and vitamin B-12 status in subjects with and without colorectal neoplasia. Am J Clin Nutr 2007;86:1064-1072.

19 Kawakami K, Ruszkiewicz A, Bennett G, Moore J, Grieu F, Watanabe G, Iacopetta B: DNA hypermethylation in the normal colonic mucosa of patients with colorectal cancer. Br J Cancer 2006;94:593-598.

20 Nakagawa H, Nuovo GJ, Zervos EE, Martin EW Jr, Salovaara R, Aaltonen LA, de la Chapelle A: Age-related hypermethylation of the $5^{\prime}$ region of MLH1 in normal colonic mucosa is associated with microsatellite-unstable colorectal cancer development. Cancer Res 2001;61:6991-6995.

21 Pufulete M, Emery PW, Nelson M, Sanders TA: Validation of a short food frequency questionnaire to assess folate intake. Br J Nutr 2002;87:383-390.

22 Balaghi M, Wagner C: DNA methylation in folate deficiency: use of CpG methylase. Biochem Biophys Res Commun 1993;193:1184-1190.

23 Barbaux S, Kluijtmans LA, Whitehead AS: Accurate and rapid 'multiplex heteroduplexing' method for genotyping key enzymes involved in folate/homocysteine metabolism. Clin Chem 2000;46:907-912.

24 Deng G, Peng E, Gum J, Terdiman J, Sleisenger M, Kim YS: Methylation of hMLH1 promoter correlates with the gene silencing with a region-specific manner in colorectal cancer. Br J Cancer 2002;86:574-579.

25 Kim YI, Pogribny IP, Salomon RN, Choi SW, Smith DE, James SJ, Mason JB: Exon-specific DNA hypomethylation of the p53 gene of rat colon induced by dimethylhydrazine. Modulation by dietary folate. Am J Pathol 1996;149:1129_ 1137.

26 Song J, Sohn KJ, Medline A, Ash C, Gallinger S, Kim YI: Chemopreventive effects of dietary folate on intestinal polyps in Apc+/-Msh2-/- mice. Cancer Res 2000;60:3191-3199.

Belshaw NJ, Elliott GO, Williams EA, Mathers JC, Buckley L, Bahari B, Johnson IT: Methylation of the ESR1 CpG island in the colorectal mucosa is an 'all or nothing' process in healthy human colon, and is accelerated by dietary folate supplementation in the mouse. Biochem Soc Trans 2005;33:709-711. Waterland RA, Jirtle RL: Transposable elements: targets for early nutritional effects on epigenetic gene regulation. Mol Cell Biol 2003;23:5293-5300.

29 Pufulete M, Al-Ghnaniem R, Leather AJ, Appleby P, Gout S, Terry C, Emery PW, Sanders TA: Folate status, genomic DNA hypomethylation, and risk of colorectal adenoma and cancer: a case control study. Gastroenterology 2003;124: $1240-1248$

30 Bariol C, Suter C, Cheong K, Ku SL, Meagher A, Hawkins N, Ward R: The relationship between hypomethylation and CpG island methylation in colorectal neoplasia. Am J Pathol 2003;162:1361-1371.

- 31 Frigola J, Solé X, Paz MF, Moreno V, Esteller M, Capellà G, Peinado MA: Differential DNA hypermethylation and hypomethylation signatures in colorectal cancer. Hum Mol Genet 2005;14:319-326.

-32 Suzuki K, Suzuki I, Leodolter A, Alonso S, Horiuchi S, Yamashita K, Perucho M: Global DNA demethylation in gastrointestinal cancer is age dependent and precedes genomic damage. Cancer Cell 2006;9:199-207.

-33 Ogino S, Kawasaki T, Brahmandam M, Cantor M, Kirkner GJ, Spiegelman D, Makrigiorgos GM, Weisenberger DJ, Laird PW, Loda M, Fuchs CS: Precision and performance characteristics of bisulfite conversion and real-time PCR (MethyLight) for quantitative DNA methylation analysis. J Mol Diagn 2006;8:209-217.

34 Nuovo GJ, Nakagawa H, Sotamaa K, Chapelle Ade L: Hypermethylation of the MLH1 promoter with concomitant absence of transcript and protein occurs in small patches of crypt cells in unaffected mucosa from sporadic colorectal carcinoma. Diagn Mol Pathol 2006;15:17-23.

35 Arasaradnam RP, Quraishi MN, Commane D, Mathers JC, Bradburn M: MYOD-1 in normal colonic mucosa - role as a putative biomarker? BMC Res Notes 2012;5:240. 
Al-Ghnaniem Abbadi et al.: Short-Term Folate Supplementation in Physiological Doses Has No Effect on ESR1 and MLH1 Methylation in Colonic Mucosa of Individuals with Adenoma

-36 Shen L, Kondo Y, Rosner GL, Xiao L, Hernandez NS, Vilaythong J, Houlihan PS, Krouse RS, Prasad AR, Einspahr JG, Buckmeier J, Alberts DS, Hamilton SR, Issa JP: MGMT promoter methylation and field defect in sporadic colorectal cancer. J Natl Cancer Inst 2005;97:1330-1338.

-37 de Vogel S, Bongaerts BW, Wouters KA, Kester AD, Schouten LJ, de Goeij AF, de Bruine AP, Goldbohm RA, van den Brandt PA, van Engeland M, Weijenberg MP: Associations of dietary methyl donor intake with MLH1 promoter hypermethylation and related molecular phenotypes in sporadic colorectal cancer. Carcinogenesis 2008;29:1765-1773.

38 de Vogel S, Wouters KA, Gottschalk RW, van Schooten FJ, de Goeij AF, de Bruine AP, Goldbohm RA, van den Brandt PA, Weijenberg MP, van Engeland M: Genetic variants of methyl metabolizing enzymes and epigenetic regulators: associations with promoter $\mathrm{CpG}$ island hypermethylation in colorectal cancer. Cancer Epidemiol Biomarkers Prev 2009;18:3086-3096.

-39 Zhu Q, Jin Z, Yuan Y, Lu Q, Ge D, Zong M: Impact of MTHFR gene C677T polymorphism on Bcl-2 gene methylation and protein expression in colorectal cancer. Scand J Gastroenterol 2011;46:436-445. 